\title{
(Re)Viewing Whistler and Sargent: Portraiture at the fin-de-siècle
}

\section{Meaghan Clarke}

Volume 30, numéro 1-2, 2005

The Portrait Issue

La question du portrait

URI : https://id.erudit.org/iderudit/1069664ar

DOI : https://doi.org/10.7202/1069664ar

\section{Aller au sommaire du numéro}

\section{Éditeur(s)}

UAAC-AAUC (University Art Association of Canada | Association d'art des universités du Canada)

\section{ISSN}

0315-9906 (imprimé)

1918-4778 (numérique)

\section{Découvrir la revue}

Citer cet article

Clarke, M. (2005). (Re)Viewing Whistler and Sargent: Portraiture at the fin-de-siècle. RACAR : Revue d'art canadienne / Canadian Art Review, 30(1-2), 74-86. https://doi.org/10.7202/1069664ar

\section{Résumé de l'article}

La comparaison entre deux portraits de femmes réalisés en 1894 et 1896 permettra de mettre en lumière la problématique du présent travail, à savoir l'identité de l'artiste et celle du critique d'art. Le premier portrait, une estampe lithographique de l'artiste James McNeill Whistler imprimée par Thomas Way, est présente dans plusieurs collections, dont celles du British Museum, de la National Portrait Gallery à Washington et de la Library of Congress (fig. 1). Le second portrait, exemplaire unique réalisé au crayon par John Singer Sargent, est conservé à la National Portrait Gallery de Londres (fig. 2). De nombreux portraits de société de ce type, mettant en scène des modèles féminins américains et anglais, ont fait l'objet d'études qui révèlent comment les artistes aimaient à flatter ou à ridiculiser ces femmes. Elles étaient en effet perçues comme des icônes culturelles et leurs portraits pouvaient être interprétés, pour citer les mots d'un spécialiste, comme " la représentation de la vision des femmes par les hommes ». Toutefois, ce n'est pas tant la construction de la féminité à travers le regard de l'artiste qui est en jeu ici, que la manière dont ce regard renvoie à celui du modèle. On peut dire que ces deux portraits évoquent les thèmes de la production artistique et de la réception critique par le biais d'un jeu de miroirs entre l'artiste et son modèle.

Il faut signaler que les deux femmes représentées dans ces portraits étaient des critiques d'art influentes qui vivaient et travaillaient à Londres à la fin du XIX siècle et au début du $\mathrm{XX}^{\mathrm{e}}$ siècle. Leur oeuvre critique a joué un rôle important dans la construction de l'image publique de Whistler et de Sargent, plaçant ces derniers au rang de références de l'art moderne britannique et américain. Il s'agit de l'Américaine Elizabeth Robins Pennells (1855-1936), critique à la Nation de New York et au Star de Londres, et d'Alice Meynell (1847-1922), critique au Weekly Register et à la Pall Mall Gazette. Le présent travail s'attachera à montrer comment les deux critiques mettent en scène l'identité publique de Whistler et de Sargent, tout en exposant les tensions inhérentes à la vie de ces artistes : celles opposant Londres et Paris, la Royal Academy et le New English Art Club, ainsi que l'art institutionnel et l'avant-garde.
Tous droits réservés (C) UAAC-AAUC (University Art Association of Canada | Association d'art des universités du Canada), 2006
Ce document est protégé par la loi sur le droit d'auteur. L'utilisation des services d'Érudit (y compris la reproduction) est assujettie à sa politique d'utilisation que vous pouvez consulter en ligne.

https://apropos.erudit.org/fr/usagers/politique-dutilisation/ 


\title{
(Re)Viewing Whistler and Sargent: portraiture at the fin-de-siècle
}

\author{
MEAGHAN CLARKE, UNIVERSITY OF SUSSEX
}

\begin{abstract}
Résumé
La comparaison entre deux portraits de femmes réalisés en 1894 et 1896 permettra de mettre en lumière la problématique du présent travail, à savoir l'identité de l'artiste et celle du critique d'art. Le premier portrait, une estampe lithographique de l'artiste James McNeill Whistler imprimée par Thomas Way, est présente dans plusieurs collections, dont celles du British Museum, de la National Portrait Gallery à Washington et de la Library of Congress (fig. I). Le second portrait, exemplaire unique réalisé au crayon par John Singer Sargent, est conservé à la National Portrait Gallery de Londres (fig. 2). De nombreux portraits de société de ce type, mettant en scène des modèles féminins américains et anglais, ont fait l'objet d'études qui révèlent comment les artistes aimaient à flatter ou à ridiculiser ces femmes. Elles étaient en effet perçues comme des icônes culturelles et leurs portraits pouvaient être interprétés, pour citer les mots d'un spécialiste, comme « la représentation de la vision des femmes par les hommes ». Toutefois, ce n'est pas tant la construction de la féminité à travers le regard de l'artiste qui est en jeu ici, que la manière dont ce regard renvoie à celui du modèle. On peut dire que
\end{abstract}

ces deux portraits évoquent les thèmes de la production artistique et de la réception critique par le biais d'un jeu de miroirs entre l'artiste et son modèle.

Il faut signaler que les deux femmes représentées dans ces portraits étaient des critiques d'art influentes qui vivaient et travaillaient à Londres à la fin du $X \mid X^{\mathrm{e}}$ siècle et au début du $X X^{\mathrm{e}}$ siècle. Leur œuvre critique a joué un rôle important dans la construction de l'image publique de Whistler et de Sargent, plaçant ces derniers au rang de références de l'art moderne britannique et américain. II s'agit de l'Américaine Elizabeth Robins Pennells (1855-1936), critique à la Nation de New York et au Star de Londres, et d'Alice Meynell (18471922), critique au Weekly Register et à la Pall Mall Gazette. Le présent travail s'attachera à montrer comment les deux critiques mettent en scène l'identité publique de Whistler et de Sargent, tout en exposant les tensions inhérentes à la vie de ces artistes : celles opposant Londres et Paris, la Royal Academy et le New English Art Club, ainsi que l'art institutionnel et l'avant-garde.
A

comparison between two portraits of women, completed in the years 1894 and 1896 , will draw attention to the issues to be raised by this essay, namely, artistic identity and art criticism. The first is a lithograph by the artist James McNeill Whistler, printed by Thomas Way, and held in several collections including the British Museum, the National Portrait Gallery in Washington, and the Library of Congress (fig. 1). The second is unique, done in pencil by John Singer Sargent, and held in the collection of the National Portrait Gallery, London (fig. 2). What do we know about how and when these portraits were completed and what place do they have within the portrait outputs of these artists during the 1890s? Many society portraits of American and British female sitters have been explored by scholars in terms of how these artists flattered and ridiculed female patrons. Women sitters were icons of cultural fashionability and celebrity - one could read these portraits, to quote one scholar, as "worked by men upon women." The recent catalogue Whistler, Women and Fashion offers alternative readings, mapping out the importance of Whistler to dress history. ${ }^{2}$ However, what concerns me here is not so much the construction of femininity by the gaze of the male artist, but rather, in a sense, a quite reciprocal gaze: the gaze of the women sitters. For in the case of these two portraits both women were influential art critics whose work had an important impact on the careers of the artists who capture them here.

The portraits bring together the themes of artistic output and critical reception since they represent two critics who were living and working in London during the late nineteenth and early twentieth centuries and who were instrumental in the construction of the public histories of both Whistler and Sargent, positioning these artists within "the modern" in British and American art: the American Elizabeth Robins Pennell (18551936), critic for both the New York Nation and the London Star, and Alice Meynell (1847-1922), critic for the Weekly Register and the Pall Mall Gazette. ${ }^{3}$ This article will first examine the portraits in greater detail to consider their exploitation of medium and technique, before broadening the inquiry to explore the growing recognition and notoriety around Whistler and Sargent in the 1880 s and 1890 s on both sides of the Atlantic, and asking how relationships cultivated with critics generated specific representations of the artists. In this period artists' public identities were to a large extent fashioned through critical reviews that appeared in the rapidly expanding popular press, often anonymously. Here I will consider the ways in which the two women critics fictionalized identities around Whistler and Sargent, and at the same time exposed the tensions inherent in these artists' lives: tensions between London and Paris, between the Royal Academy and the New English Art Club, and between the establishment and the avant-garde.

The portrait print of Elizabeth Robins Pennell was initially a drawing made on transfer paper and shows her in her Buckingham Street flat in front of the fireplace: it is entitled Firelight. It was exhibited in London at the Fine Art Society in 1896, in an exhibition of Whistler's lithographs to mark the centenary of 
Figure I. James McNeill Whistler, Portrait of E.R. Pennell, 1896. Lithograph, $19.1 \times 14.9$ $\mathrm{cm}$. Autographed proof by Whistler from the Pennell Collection, Library of Congress, Washington; Photogravures by Messrs. F.A. Ringler Co., Printed by Messrs. Peters Brothers (Photo: courtesy of University of Sussex).

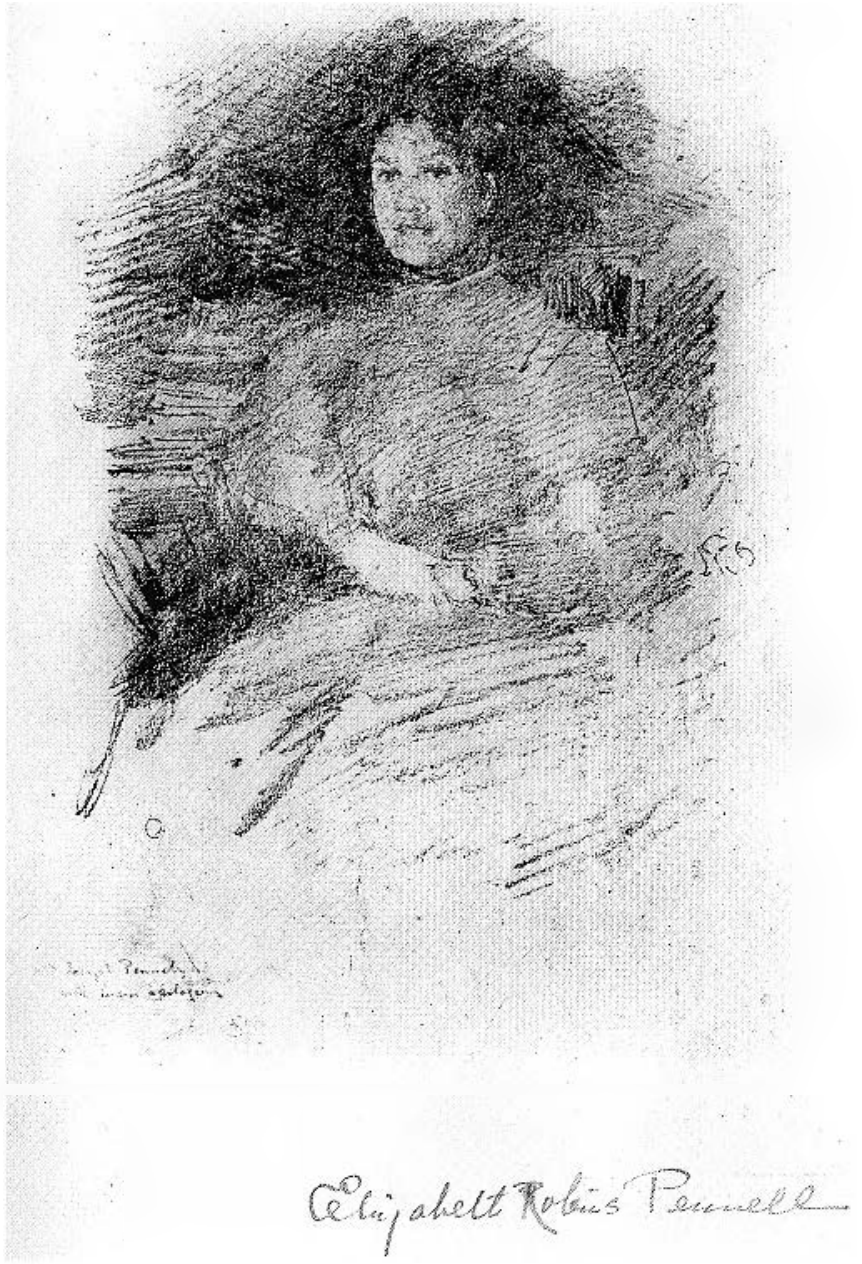

the medium. ${ }^{4}$ The print is particularly distinctive for its spontaneity and attention to the play of light across the face of the sitter. Pennell and her husband, the printmaker Joseph Pennell, later described how the portrait was completed: "[Whistler] worked on into the darkness, especially in the portrait of E., done while the firelight flickered on her face and on his paper." 5 Margaret MacDonald observes that Whistler's method employed broken flickering lines of the crayon to catch the essence of the person and the firelight. ${ }^{6}$ The 1890 s marked a return to lithography for Whistler, and I will touch on the significance of this method of printmaking at greater length later in this article. Two years earlier Whistler had completed the rapid lithograph portrait of his friend the Symbolist poet Stéphane Mallarmé, in which the sitter was posed, like Pennell, in front of a fire (for so long that he reportedly burned his legs). Contemporaneously with this work Whistler completed a portrait of Pennell's husband, which was used as the frontispiece
Figure 2. John Singer Sargent, Alice Meynell, 1894. Pencil, $36.2 \times 21 \mathrm{~cm}$. National Portrait Gallery, London (Photo: National Portrait Gallery, London).

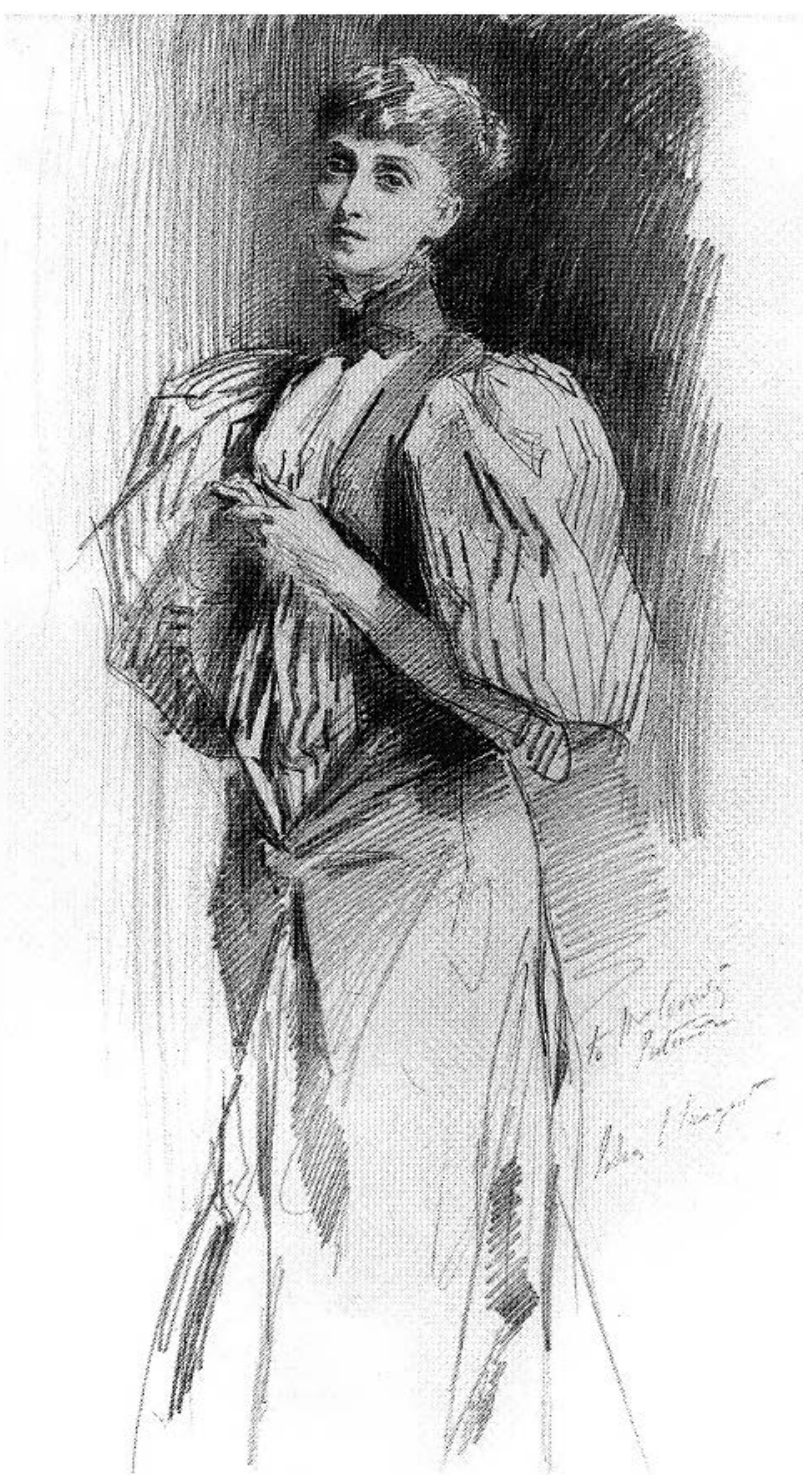

for a book they wrote jointly and entitled Lithography and Lithographers, published in 1898.

The Sargent portrait of Alice Meynell, in pencil, was similarly later reproduced as the frontispiece for a published collection of the sitter's poems. ${ }^{8}$ The choice of the full-length pose is in keeping with the society portraits Sargent was producing of English and American women at the time. However, it differs from Sargent's more sensuous portraits of wealthy celebrities such as The Misses Vickers (fig. 3) or Lady Agnew of Lochnaw (National Gallery of Scotland), which was shown at the Royal Academy in 1893. ${ }^{9}$ These portraits of women are marked by their sitters' open poses as the women perch languidly on furniture, whcreas Meynell's dress and closed stance perhaps 


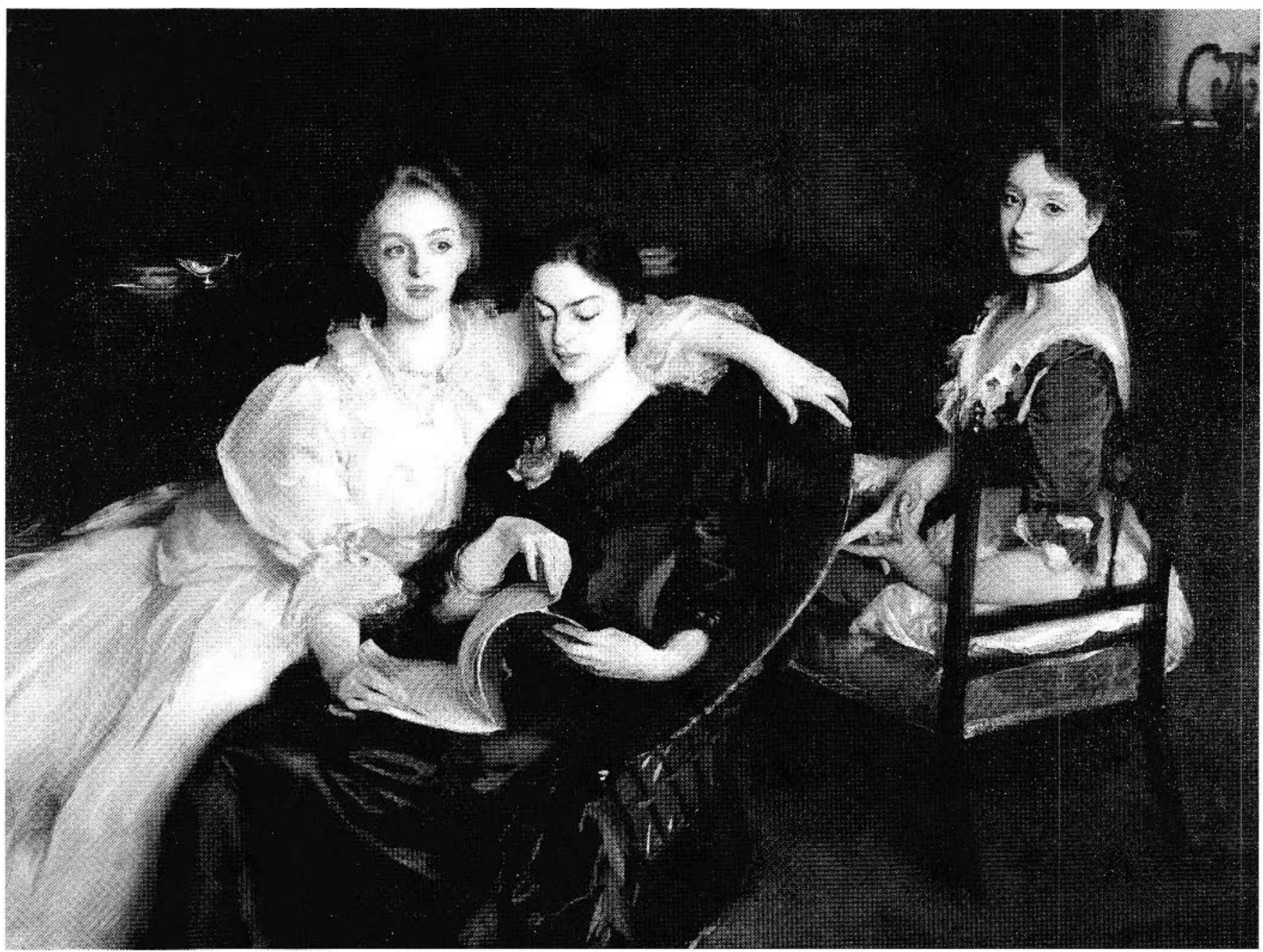

has more similarities with the portraits Sargent produced of women such as Mrs. Robert Harrison (fig. 4). The style and fabric of the dress is ambiguous and the arms are held across the body with hands clasped. Yet, in comparison to Mrs Robert Harrison, Meynell's stance is self-possessed as she turns to look directly back at the artist. Her head is slightly tilted and her gaze contemplative, while she retains a certain confidence and presence.

Women art critics were not new subjects for either of thesc artists. Sargent produced two portraits of another woman art critic, Vernon Lee (Violet Paget), one in oil (1881, Tate Gallery) and one in pencil (1889, Ashmolean) (fig. 5). Both are portrait heads rather than full-length studies, but likewise avoid the format of society portraiture. The Tate portrait of the bespectacled Lee in a white collar suggests her status as an advanced New Woman writer before the label had been coined. While Whistler had earlier painted a portrait of the critic Gertrude
Campbell, we know it only from an extant engraving, but it follows the format of full-length society portraiture. Campbell was also Lady Colin Campbell at the time and in the middle of a celebrated divorce case.

For the Pennell and Meynell portraits, Whistler and Sargent employed materials that represent a certain ephemerality. Paper, pencil, crayon and ink - as opposed to oil on canvas - indicate impermanence and a rapid mode of production. In her study of portraits of women authors in the National Portrait Gallery, Lara Perry points to this gender binary in nineteenth-century portraiture. The materiality of portraits of women intellectuals, in minor media such as watercolour, pencil on paper, or miniatures, implies their own fragility and signalled moral beauty over the sensuous beauty conveyed by large oils. ${ }^{10}$ Neither image is very large; the Sargent portrait is slightly larger $(36.2 \times$ $21 \mathrm{~cm}$ ) than a standard sheet of paper, and the Whistler is smaller $(19.1 \times 14.9 \mathrm{~cm})$. The small, sketch-like nature of both 
Figure 4. John Singer Sargent, Mrs. Robert Harrison, 1894. Oil on canvas, $157.8 \times 80.3 \mathrm{~cm}$. Tate, London (Photo: Tate, London, 2005).

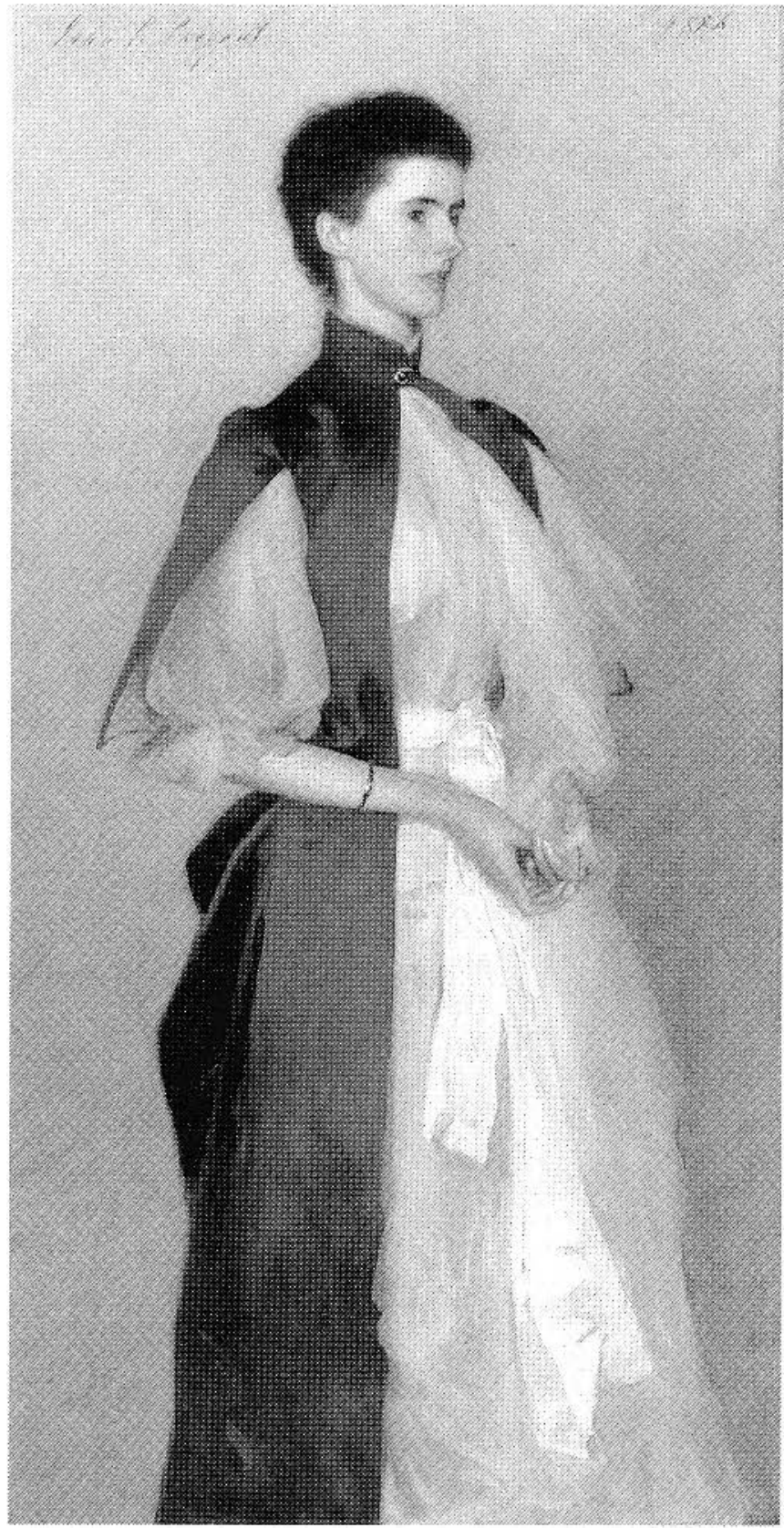

images indicates their informality and indeed their mode of production in comparison to large studio portraits. At the same time, the fact that these are not large-scale portrait commissions for wealthy celcbrities implies a different kind of social transaction. Although pencil on paper combines immediacy and portability, when framed the Sargent portrait grew in size substantially - it remains in what appcars to be its original frame $(74 \times 61 \mathrm{~cm})$, boldly surrounded by mottled red and brown. ${ }^{11}$ The Whistler portrait inverts the professional studio setting.
Instead, it is located within the salon space of the sitter, an alternative spatial possibility. It might appear as if the portrait setting evokes a more personal interior space, more often associated with women. However, for Pennell the private space of her flat was also a public space; during the 1890s her Thursday evening salons were particularly well attended by a band of journalists and artists. In both portraits the head is most finished while the body is more sketch-like, and in the Pennell portrait in particular the contrast of light and dark accentuates the reflection of light on her skin in the firclight. In comparison to some of Whistler's other lithographs of the period - linc drawings of facial features - Pennell's face is shaded and her eyes are particularly dark and piercing.

During the mid-nineteenth century educated women werc generally portrayed with devices such as caps, books, and desks to indicate their status. ${ }^{12}$ However, in these portraits nothing denotes their profession. Sitting without a pen or desk, the women have their hands clasped, and in the case of Meynell her fingers are piously intertwined. Yet, the gesture of clasped hands implies a closed, rather self-possessed pose. In contrast to contemporary society portraits there is no suggestion of décolletage, nor arc these sleeveless evening dresses - the high collars function in a manner similar to the austerity of the cap or cloak. The complete lack of risqué detailing points to their respectability and professionalism; the high collars and puffed sleeves were typical of 1890 s daywear. As Aileen Ribeiro observes, the dress style in Whistler paintings is often enigmatic, and this is certainly true in the portrait of Pennell. ${ }^{13}$ Mcyncll wears a striped dress with no discernable waist, beneath an over-mantle and, surprisingly, neither woman wears a hat although they were both photographed in them. The dress of both figures is presumably what they happened to be wearing that particular day, rather than a sartorial choice that had been considered and reconsidered by sitter and artist. In the Meynell portrait the high neck and drapery elongate the body, creating an illusion of height and authority; this was an image that she herself attempted to construct in her everyday life through fabric, hats, and hecls. ${ }^{14}$

However, in these portraits the sitters are also marked by the ephemera of modernity, for they were journalists, rapidly producing columns for mass reproduction in the weekly and daily press. ${ }^{15}$ Although these portraits were not painted in anticipation of the walls of the Royal Academy or New Gallery that scason, their very reproducibility increased the possibilities for their circulation alongside texts the sitters themselves had written. Thus, the portraits could play into a directed selffashioning within an existing culture of literary and artistic celebrity. Yet, the artists' annotation is present on both portraits. Mcyncll's portrait is addressed to Coventry Patmore. Similarly, the Whistler portrait is addressed to her husband, 


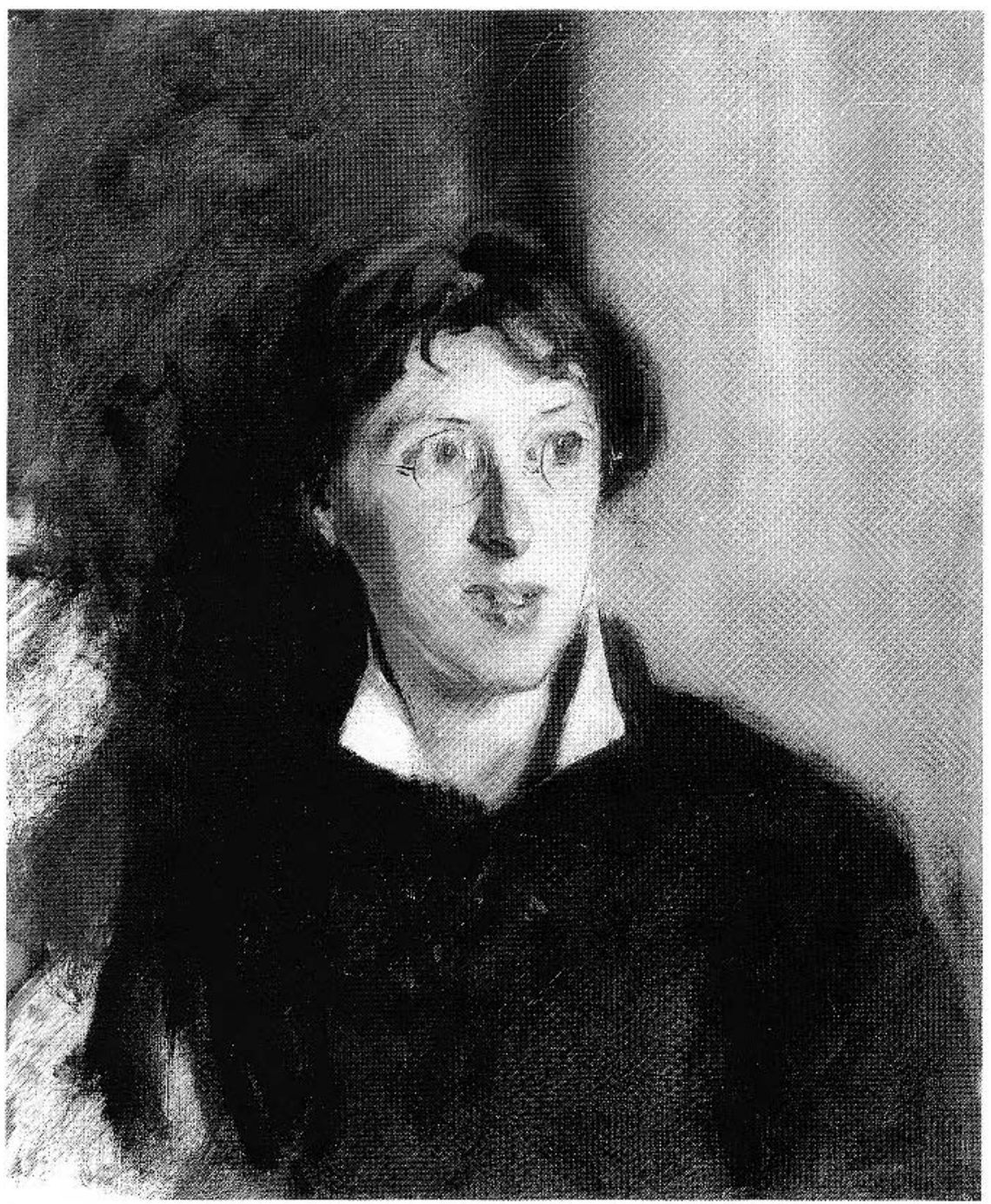

but back at the artist and the canvas, for the sitter/critic will in turn review the "canvas." The question of the gaze is not simply related to visual relations, but also to actual changes in power relations. Paul Barlow has demonstrated the inherent tension in depicting an author whose writing influences her or his own depiction. Barlow argued that John Everett Millais struggled to evoke Carlyle's physicality through portraiture as well as his ideas around "authenticity," which provided an ethos for the new National Portrait Gallery. ${ }^{17}$

At this stage in our analysis it is important to unravel these portraits in order to begin to consider the significance of these two images of working women for these artists, both already renowned for obtaining lucrative portrait commissions. Both Meynell and Pennell earned their living by looking at and writing about contemporary art. Thus these portraits speak to the complex relation between artist and critic in an age of mass journalism and the new significance, for the artist, of their popular critical reception.

During the 1880s and 1890s James McNeill Whistler moved between the metropoles of London and Paris. In London, he was one of the most vocal advocates of the new painting, having studied and exhibited in France before moving to London, where he gained renown in the 1870s with his Nocturne series, one canvas of which - Nocturne in Black and Gold: The

thereby also implying at least initially a private, gift-giving relationship.

In her examination of eighteenth-century portraiture, Angela Rosenthal highlights the psychosocial situation of the portrait painter's studio and the danger implied by an exchange of gazes between male artist and female sitter. These heterosexual relations may be nullified by the narcissism of the female sister who does not return the look. Rosenthal considers the intersubjective exchange resulting from a reversal of gender roles between a female artist and a male sitter. ${ }^{16}$ In terms of gender binaries it seems as if the Sargent and Whistler portraits are conventional in that they are female sitters painted by male artists. Although the gendered transaction between artist and sitter is not reversed, it is in a sense destabilized. The artists are male, but the female sitters gaze not at the proverbial mirror,
Falling Rocket (1875, Detroit Institute of Fine Art) - was denounced by Ruskin. ${ }^{18} \mathrm{He}$ used a wide variery of venues for exhibiting, in Paris winning a medal at the Salon in 1883, while in England he became president of the Society of British Artists and arranged for Monet to exhibit there in 1887, although he himself moved to Paris in $1892 .{ }^{19}$ Whistler has been seen as a figure who did not fit easily within a national school; like Sargent he was an American by birth, hovering berween France and Britain. The nature of his identity and role as a catalyst in a cross-channel artistic community was constructed by Whistler himself, as he made prolific contributions to artistic debate, punctuated by his shifting alliances with artists such as Walter Sickert. ${ }^{20}$

What I am interested in, however, is the development of his critical relationship with an individual less notorious than 
either Ruskin or Sickert. This was the art critic Elizabeth Robins Pennell who, like Whistler, travelled between London and Paris, in her case reporting on exhibitions. Although Whistler had already appeared in Pennell's diary and exhibition reviews, it was 1892 that marked the beginnings of her contributions to the fashioning of "Whistler as artist" for the public. Whistler's retrospective exhibition at the Goupil Gallery opened in April and was followed by Pennell's review article in the Nation, entitled "Whistler's Triumph." The exhibition was a tremendous success, attracting a thousand visitors on the first day. ${ }^{21}$ Pennell sought to not only ratify Whistler's already cstablished celebrity, but to position him within a new modern historiography of art. His prints, she claimed, "have brought enormous prices when productions of popular Academicians have been resold for a song instead of the original thousands; while at the present moment all the world is rushing to see the exhibition of Mr. Whistler's paintings." 22 Pennell's opening sentence immediately conjoins the aesthetic and economic, revealing an acute awareness of the role of three overlapping markets in relation to Whistler's art: France, Britain, and America. She pinpointed the presence of New York art dealers at Christie's and Sotheby's as a reason for the increasing prices, while the British response had been further aided by the purchase of Arrangement in Grey and Black No. 1: Portrait of the Painter's Mother, ca. 1871, by the French government.

For her American readers, Pennell carefully constructed an identity for Whistler as an American artist. Her art reviews in the Nation paralleled her support of Whistler in the Star and elsewhere. In the Goupil review, Pennell drew attention to Whistler's American heritage, admonishing the American public for neglecting to commission his work. "It should not be forgotten in America," she wrote, "that Mr. Whistler is an American of Americans; it may therefore be appropriately asked, What has America done for him? It has treated him with - if possible - even more ignorance and coldness than England."23 In Pennell's concluding paragraph, the reason for her appeal to American nationalism was clear: Whistler's Arrangement in Grey and Black may have been acquired by the French the previous year, but his work also belonged in American collections. She additionally felt his expertise had been neglected in a recent large-scale building commission:

There is in Boston, I believe, at the present moment a public building in process of decoration by Americans. Has Mr. Whistler, the greatest decorator America has ever produced, been asked ... [I]t is at least not too late for Americans at once to endeavor to obtain from him one, if not more, of the few examples of his work still in his possession, which, however, before long may be distributed among galleries everywhere except in his native land. ${ }^{24}$
The reason for Pennell's campaign was almost certainly that Whistler's compatriot Sargent had been commissioned to do murals for the Boston Public Library in $1890 .{ }^{25}$ In fact, Whistler was asked to do a mural for the Boston Public Library, but the project never advanced further than an oil sketch of the landing of Columbus. ${ }^{26}$ As was Elizabeth Robins Pennell herself, Whistler was an "outsider": an American living in London. As the European correspondent for the Nation, Pennell thus occupied a unique position as a purveyor of Whistler's art for English and American audiences simultaneously. She contributed to the growing recognition of and industry around Whistler in the 1880s and 1890s in America: an art market that was becoming increasingly lucrative through commissions and collectors.

However, Pennell's concern with Whistler's artistic reputation was not limited to their shared experiences as American expatriates in London and to his avant-garde status. In addition, the "enormous prices" fetched by his prints intrigued her. Her article had opened with a pronouncement about the burgeoning print market, and it was this aspect of Whistler's artistic production that would become central to her relationship with the artist. The portrait of Pennell immediately gestures to this significance. The play of light across the surface of the grainedstone texture transfer paper and the chiaroscuro effects allude to Whistler's experimentation with transfer paper during the period 1895-96. The portrait was signed with a printed version of Whistler's butterfly monogram and a just faintly visible graphite butterfly. In addition to Whistler's butterfly signatures, the portrait was inscribed to her printmaker husband, "To Mr. Joseph Pennell with sincere apologies." Despitc this apparent apology, the portrait was sufficiently good for Whiscler to add it to his show at the Fine Art Society, which had already opened. That exhibition was followed in October by Joseph Pennell's exhibition of lithographs of the Alhambra, also at the Fine Art Society. It was this exhibition that resulted in a spectacular court case. Walter Sickert wrote a letter to the Saturday Review claiming that Joseph Pennell's transfer lithographs exhibited at the Fine Art Society were not made using a genuine artistic process and were fit for " 3 penny papers," not for gallery walls. In fact, these prints were made using a sheet of transfer paper, rather than crayoned directly onto the stone. They were thus more easily transportable and also had the convenience that the image was not reversed. ${ }^{27}$ As a result, Pennell sued Sickert and Frank Harris, editor of the Saturday Review, for libel. At the time, Elizabeth Robins Pennell was already writing a history of lithography in periodicals as well as the volume for which Whistler had produced the Firelight lithographs. In the press she immediately took aim at Sickert in both pseudonymous and signed articles. They included one entitled "The Master of the Lithograph - J McNeill Whistler," which pointedly observed 
that Whistler used the transfer lithograph, and the illustrations reproduced with them included examples of the prints. ${ }^{28}$ The resulting debacle became all the more sensational when Whistler was called as a witness for Pennell. (Joseph Pennell had already worked in lithography with Whistler in Paris in 1894.) In the end, Sickert was found guilty of libel and he and Harris were fined $£ 50.29$

As Sarah Burns argues, Whistler was actively involved in fashioning his own identity through spectacle. ${ }^{30}$ However, his fictional identity was also narrated and shaped by an author who had first-hand knowledge of the value of sensation. Pennell had fuelled the press furor around two cases involving her husband, firstly against the Royal Academician Hubert Herkomer in 1891, and later by Sickert in 1896-97. Her letters and diary attest to constant negotiation with editors and dealers on behalf of herself and her husband. As Julie Codell has recently suggested, in their later biographics of Whistler the Pennells normalized and sanitized the artist, refuting his concern with money. ${ }^{31}$ However, Elizabeth Pennell's articulation of Whistler's public self was carefully attuned to developing paradigms in the writing of art history. In an 1896 article on the Pre-Raphaelite Brotherhood she said:

The main facts are too well known and have been the inspiration of too much "copy" to be in need of reperition. The Pre-Raphaelites were rebcls - rebels against Academic convention and tradition . . But whatever neglect or insult was offered to the work of the Pre-Raphaelites was always sure in the end to prove the kindest of advertisements. Better, after all, to have one's painting called an atrocity, or abomination, or any other hard name, than to have absolutely nothing said about it. ${ }^{32}$

The construction of the Pre-Raphaelite Brotherhood as a national school of painting was highly contested during this period. In her 1896 article Pennell was of course contributing to that same abundance of "copy" that she mocks, but at the same time she was revealing her awareness of the value of the "artist as rebel" narrative in the art economy and reinscribing the story with Whistler as an "atrocity" in the eyes of the Academy. In London, Pennell emphasized Whistler's victimization by the press and the establishment, positioning him as an "outsider" to the Royal Academy. In a note on a RA dinner, Pennell asserted that

the President had neglected to mention the leave-taking of Whistler from Britain. The fact that he shook the dust of London off his feet, owing to the systematic and increasing pcrsecution that he received at the hands of the Royal Academy individually and collectively, will be about the only rcason for their names to be remembercd for posterity. ${ }^{33}$
Furthermore, she described the 1893 Grafton exhibition of Whistler's Lady Meux:

I have as yet made no reference to Mr. Whistler's stately "Lady Meux," the beautiful harmony in black and silver, through it is one of the most masterly paintings in the collection, and though the fact that a centre of honor in the largest room has been reserved for it is as significant as the absence of all Academicians save two - Mr. Watts and Mr. Orchardson - from the gallery. The old idols are being gradually dethroned. ${ }^{34}$

Indeed, by 1895 Whistler had realized the value of Elizabeth Robins Pennell's criticism and contacts. In a letter to his sisterin-law he instructed: "I wired you today that you should be sure to send cards to Mr and Mrs Pennell. They could put anything in the papers, and she would do it very nicely." ${ }^{35}$

During this period John Singer Sargent was also based in Paris and London. Like Whistler, he was linked with modern French art practices and exhibited in venues on both sides of the channel. He had studied in Paris with the portrait painter Carolus-Duran, and his early work included plein air painting and portraits of French and American sitters. Like Whistler, he became known for aesthetic portraiture. It was the scandal surrounding his 1884 portrait of Madame Gautreau, or Madame $X$, that encouraged Sargent to move to London, but there critics were wary of his alliances with the avant-garde. $\mathrm{He}$ exhibited in a variety of venues, including the New English Art Club (formed by a group of French-influenced artists) and the Royal Academy, but in London his progressive work was still largely dismissed by the establishment.

One of the critics was Alice Meynell, who wrote for the London Art Journal and Magazine of Art as well as for the Weekly Register, a Catholic journal she edited with her husband. In the latter, her review of Sargent's 1886 contribution to the Royal Academy exhibition, The Misses Vickers, was critical of his technique:

Mr. Sargent is eminently a virtuoso; he executes for the sakc of execution, and imposes his achievement upon us somewhat. His principal picture is the portrait of the Misses Vickers which was at the salon ... The three ladies are posed with charming effect, and the individuality of the distinguished young heads is delightfully rendered. But cven granting that the faces are in the harsh light of a wide north window open full upon them, with the rest of the room in shadow, the lights of the carnations are forced up in a manner that does violence to nature. Everything is exaggerated, nor with vulgar, but certainly with vain, exaggeration. The whole thing is brilliantly clever and gay, but conceited 
Figure 6. John Singer Sargent, Carnation, Lily, Lily, Rose, 1885--86. Oil on canvas, $164 \times 153.7 \mathrm{~cm}$. Tate, London (Photo: Tate, London, 2005).

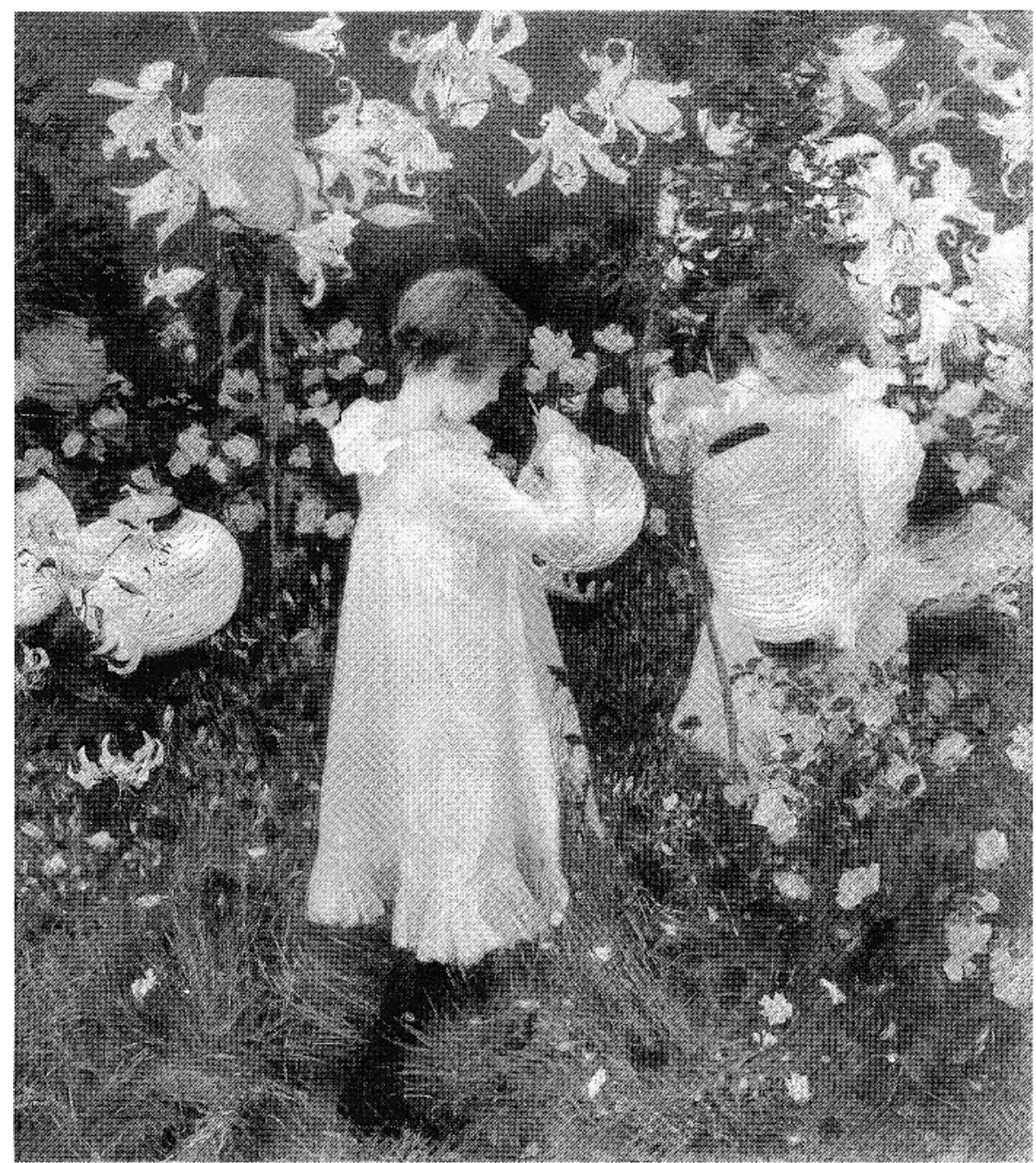

The flesh and the whitc draperies in the rosy and violet light are exquisitely beautiful, but we have to look for them in a maze of improbabilities. We cannot say impossibilities, for Mr. Sargent is master of the situation - we cannot tell whether roses shone upon by Chinese lanterns in twilight would take these tender, cool violet tinges, and we shall never test the point; but it must be owned that even if he is right he is not convincing. ${ }^{38}$

Meynell's concerns about Sargent's technique, specifically the veracity of his plein air study of light, is interesting, given that by this time Sargent had been experimenting with these new working methods alongside Monet, an artist Meynell had already praised in the collection of Captain Hill of Brighton. ${ }^{39}$ Sargent's Claude Monet Painting by the Edge of the Wood (1885, Tate Britain) gives visual evidence of this link between the two artists. Indeed, by the following week she had changed her mind:

For our own part such doubt as we
had as to the effect of atmosphere
and light in the "Carnation, Lily,
I.ily, Rose" is solved by the now
known fact that Mr. Sargent de-
voted the evenings of two summers to the study of his subject. The picture is eminently a work of selection among the materials of nature; but we have the painter's care and industry as a guaranty of the fact that though the truth is fastidiously selected it is not forced. ${ }^{40}$

She added, "Hasty critics have accused the picture of audacity, but audacity is rather to be predicated of the potterers, the old school of our academy which certainly does not devote two summers to watching one of the moods of twilight among flowers." ${ }^{41}$ Here Meynell's re-positioning in relation to this work can be traced to her own critical trajectory through Monet. But the incongruous nature of her about-face can also be charted in the context of contemporary responses to Carnation, Lily, Lily, Rose. In her recent study of the critical reception of this piece, Anne Helmreich argued for a rethinking of the modernist paradigm: "[T]he art world was not divided simply into, on the 
one hand, heroic avant-garde artists who championed the new, and, on the other, conservative forces of resistance; rather, it was a slippery field in which positions were quickly staked out and then ripped out and staked again." 42 In her writing Meynell appeared to exemplify this slippery field, and through the process of her responses to the Chantrey painting she had staked out a new position vis-à-vis Sargent. However, that position was one in which modernism was simultaneously occluded by nationalism. Meynell's criticism shifted from Carnation, Lily, Lily, Rose itself to its choice for the Chantrey Bequest: "[I]n these proverbially bad times it is rather hard that one of the few bits of official patronage in England should be given to an alien." ${ }^{43}$ It was this question of national identity in British art that had already become particularly fraught during the 1880 s and 1890 s, with artists and critics vying to establish a distinctly British school and historiography. Sargent's French painting style only added to the controversy. Meynell's own life trajectory adds irony to this complaint because, like Sargent, she had been raised in Italy, returning to England as a teenager.

By the following year her attitude had completely changed. She proclaimed that Sargent's paintings were amongst the "most striking and living portraits" at the 1888 Royal Academy. She also devoted a two-article series in the Art Journal to the Newlyn School: members of the New English Art Club, who also employed French plein air methods. ${ }^{44}$ Thus, despite her early concerns about his work, Alice Meynell developed a friendship with Sargent. By the 1890s his fame had increased - as had Meynell's (she had begun to write for the Pall Mall Gazette) and they were beginning to move in the same circles. He in fact wrote to convey his appreciation for her Pall Mall Gazette "Wares of Autolycus" columns. ${ }^{45}$ Meynell's circle also included John Lane, publisher of The Bodley Head, who reprinted collections of her articles and essays. In a letter to Lane in the 1890s, she attempted to coordinate a Saturday evening dinner amongst several celebrated editors and writers: "Could you not come by an earlier train? The fact is I have said 7:30 to Aubrey de Vere and Mr. Henley and Coventry Patmore; otherwise I would make the hour later, so as to fit your train." 46 The letter signals her role in the aesthetic elite, and more specifically her role amongst the Catholic avant-garde in London. Meynell's work was lauded in the press by arbiters of Victorian culture, and her name was suggested to succeed Tennyson as Poet Laureate. ${ }^{47}$ Max Beerbohm reviewed a book of her essays, mocking her veneration in this literary and journalistic sphere: "The crowd is the reading public; the mounted policeman is Mr. John Lane; the guardsmen are the literary critics; the lady is Mrs. Meynell; the homely carriage is her new book; the stalworth Highlanders are Mr. Coventry Patmore and Mr. George Meredith." 48

It was Sargent's 1894 portrait of Coventry Patmore (fig. 7) that led to his portrait of Meynell. She had accompanied Patmore to Sargent's studio and he had requested that Sargent do her portrait. The signature on the portrait indicates that it was addressed to Patmore, thus revealing a triad, a relationship that was not limited to artist and critic. Rather, the portrait is a gift given by the artist to Patmore, the famous poet; the subjectsitter becomes the object of the exchange. Patmore died two years later, at which point it was the relationship of artist and critic that came to the fore. The portrait remained in the possession of the sitter until it was given to the National Portrait Gallery after her death.

By 1900 Meynell was a transatlantic presence. Her poetry and prose were increasingly popular, and she undertook a lecture tour of America the following year. In a 1902 letter she described a visit to Sargent's studio, where she admired his Crucifix and Trinity for the Boston Public Library. ${ }^{49}$ As art critic for the Pall Mall Gazette Meynell commended Sargent's work both at the Royal Academy and the new Carfax Gallery. She also took issue with criticism that had been made of his technique in his portrait of the Italian actress Eleanora Duse: " $T]$ he word dash is often used by those who write about Sargent's work, it is singularly astray when his paintings are in question ... no sketch could be slighter, but nothing of Mr. Sargent's is more charged with power and genius." 50

Sargent requested that Alice Meynell write the introduction for a luxury volume of 62 photogravures of his work, which was published in London and New York by Heinneman in 1903. Trevor Fairbrother identifies 1903 as the year Sargent's reputation soared. It was the year that not only saw the publication of the Heinneman book, but also in which Sargent was awarded exhibition medals and honorary degrees by the University of Pennsylvania and then Oxford. ${ }^{51}$ The book illustrations included the famed Sargent works already mentioned, as well as a range of others, from early impressionist pieces such as Paul Helleu Sketching with his Wife of 1889 to society portraits such as Mrs. Carl Meyer and her Children of 1898. Sargent was exceedingly grateful for Meynell's introductory essay and wrote to express his "great pleasure and feeling of gratitude." In particular he valued her expertise in composing a review essay that avoided log-rolling: the "distinctions and oppositions which give your essay the character of study in spite of its very high praise." 52 The book was translated and published in French two years later, and was republished in English, with an introduction by J.B. Manson and with 15 additional plates, in 1923 .

In her introduction to Sargent's work, Meynell returned to the question of nationality, but this time in his sitters:

It is evident that Mr. Sargent has keen sight for the signs of races; there is as it were the knack of Spain in his "Jaleo", something neither Italian nor Oriental ... In the "Javanese Dancer" the flat-footed, flat-handed action of the extreme 


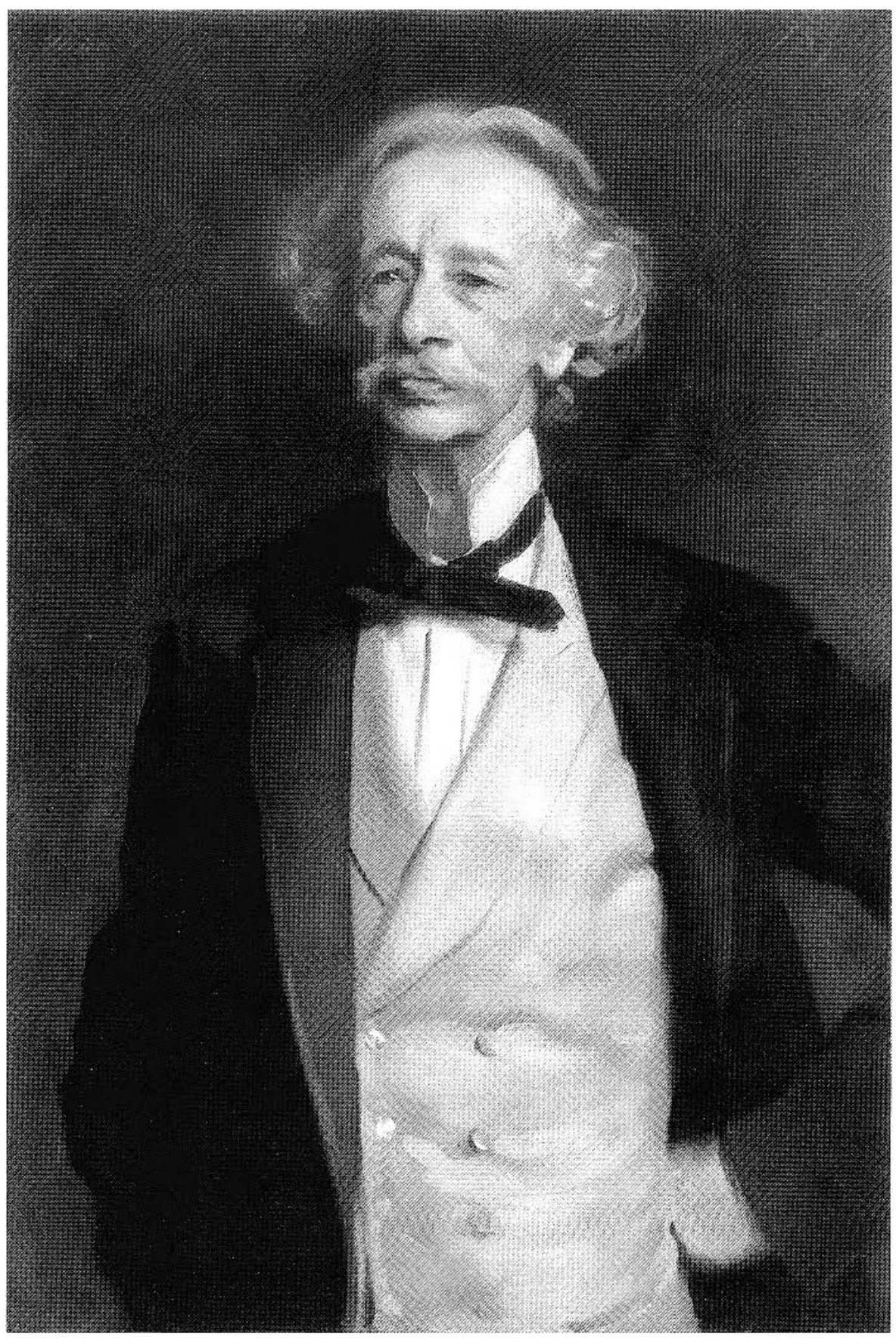

for example - the eye has the look of America, the national habit is in the figure and head ... In like manner, Mr. Sargent paints an Englishwoman with all the accents, all the negatives, all the slight things that are partly elegant and partly dowdy - one can hardly tell which of those two - the characteristics that rcmove her, further than any orher woman, from the peasant and the land, further than an artificial $\mathrm{Pa}$ risian ... The Hebrew portraits present morc obviously, but also not less subtly, the characters of race; as do all those, pictures or drawings, in which Italians are studied. ${ }^{53}$

Ormond and Kilmurray, reading Sargent through Meynell's text, point out that Sargent was too keen an observer to blur all national distinctions. Yet, these distinctions are not limited to national. Kathleen Adler cites Meynell in her analysis of Sargent's portraits of the Jewish art dealer Asher Wertheimer and his family in the context of contemporary attitudes towards Jewishness. ${ }^{54}$ Meynell reads facial and bodily characteristics through an imperialistic Oriental and Occidental binary where there is slippage, but also across differing Anglo and continental European ethnic identities. ${ }^{55}$ Meynell's extended interpretation of Sargent's work in the context of racial types could also be read in the context of her own interest in science. In addition, her daughter's marriage to the eugenicist Dr Caleb Saleeby in 1903 meant that family discussions encompassed physiology and evolution. ${ }^{56}$ Thus her application of racial physiognomy to Sargent's work is not surprising. In contrast to her earlier

East - a grace that has nothing to do with Raphael - is rendered with a delightful, amused, and sympathetic appreciation: the long code of Italian conventions disappcars: the slender Javanese dance has weight - a confession of gravitation, whereas the occidental dance makes light of it. All that is alien there, the painter sees in the quick. When Mr. Sargent paints an American - the portrait of Mr. Roosevelt, assertions about his nationality, Sargent's own "alien" identity shifts. Instead of a foreign "American," it is his very experience as an "Anglo-Saxon child" living abroad that has enabled his profound perception of the English.

In her essay Meynell also returned to Carnation Lily, Lily, Rose, reversing her original pronouncements on the piece. Now she praised its truthful study of twilight: "the fine violet tints 
that artificial light lends to an evening air, and with white as lovely in its coolness as the white of Titian." However, it was in her conclusion that Meynell invoked Sargent's position in the modernist historiography of art. "He has indeed," she wrote, "shown in modern times how high that height reaches - the height of the 'power of hand' made manifest, the manifestation being an essential part of the bcauty of that power. He is therefore one of the family of Velasquez, and no less than his chief heir." 57 Thus, finally Sargent is positioned as the direct descendent of European art - a lineage that obfuscates the shifts across Anglo/European identities.

To conclude, although Elizabeth Pennell's writings on Whistler were only intermittently visible during the 1890 s, her pseudonymity enabled her to claim discursive authority in a variety of contexts. It was not until 1908 that Pennell and her husband published the first of their three books on Whistler, and it was at this point that copies of the lithographic portrait of Elizabeth Robins Pennell was included in the volume. ${ }^{58}$ Correspondence from their editor, T. Fisher Unwin, reveals that the Pennell portrait almost appeared in the 1898 volume on Lithography and Lithographers:

Again with regard to a portrait of Mrs. Pennell, am I not right in thinking that there exists a lithograph of her; if so would you like to ask Mr. Whistler to allow it to be reproduced as a process block in your book, and at the samc time you might say that we also propose to use it in an illustrated brochure; I am sure you can put this to him with greater literary power than I can. ${ }^{59}$

Financial considerations intervened and only Joseph Pennell's portrait appearcd as the frontispiece, but Fisher Unwin was only too aware of the purpose of the author portraits: "We should be glad if you would send us a photograph of yourself and one of Mrs. Pennell ... the photographs to be reproduced in any reputable magazine that may wish to 'boom' lithography." 60 Intriguingly, it was in 1921 that Whistler's portrait of Elizabeth Pennell resurfaced as the frontispiece to a new book, The Whistler Journal, wherein she took the unique tactic of actually writing her own signature beneath his - thus effecting a double writing, a play of countersignature. Her signature appeared in cursive script, in contrast to Whistler's pictographic monograms, which were in a sense elided with the formal qualities of the print. This limited edition volume also sought to authenticate and re-value the original print, triply "imprinting" the signature of the artist, sitter, and author. The use of the signature or "autograph" of the sitter was employed during the nineteenth century for portrait reproductions such as engravings of famous celebrities or indeed photographs. ${ }^{61}$ Elizabeth Pennell drew upon this historical mode in order to endorse her portrait, but the portrait is also caught in the legal context of Whistler studies. In this case the signature grounds a portrait that has been literally "erased" due to the Pennells' fallout with Whistler's executrix, Rosalind Birnie Philip. Katharine Lochnan observes that the original stone was destroyed by Goulding in 1904 and the Ways must have pulled many impressions in $1898 .{ }^{62}$ Indeed, the Pennells' first biography of Whistler was the subject of considerable legal wrangling with Birnie Philip, and thus the positioning of the doubly signed portraits as the frontispiece was historically weighted.

The relationship between signature and countersignature, the one authorizing and guaranteeing the other, also mimics the relationship between author and reader as analysed by Derrida. The work - in its very singularity or uniqueness - is only constitured through effects of both signature and countersignature:

There is as it were a duel of writing and reading, in the course of which a countersignature comes both to confirm, repeat and respect the signature of the other, of the "original" work ... Thus redefined, the concept of countersignature gathers up the whole paradox: you have to give yourself over singularly to singularity, but singularity then does have to share itself out and so compromise itself, promise to compromise itself. ${ }^{63}$

It is just this metaphorical play of signatures between author and reader, artist and viewer, or artist and critic that is played out in the real signatures of Pennell and Whistler in the Pennells' biography of Whistler. Derrida uses the example of traveller's cheques to explain that an author's signature is never complete without the countersignature of the reader, and that this is just what makes the text a text: the fact that it is always open to further countersignatures. ${ }^{64}$ The signature of Whistler is immediately compromised and divided by the possibility and necessity of critical countersignature. In the context of visual art the fetish of the signature appears to carry even more force, but Pennell's countersignature of Whistler's work here reminds us that art history is and has been constructed through not only the signature of the artist but also the seemingly invisible countersignature of the critic and criticism in general.

Unlike Pennell and Whistler, Meynell and Sargent became figures at the centre of London's literary and artistic elite. Thus, although their relationship was similarly symbiotic, by the early twentieth century they were inscribing themselves as "insiders" in the cultural establishment. One would imagine that Meynell, the ascetic individual revealed through biographies, would be reticent about the public circulation of her portrait. However, in 1903 her portrait illustrated her article on Sargent for the World's Work, wherein she puffed the "magnificent" album of reproductions. And Meynell's was in fact the last named por- 
trait in this luxury edition of Sargent photogravures. Thus, in a sense, she frames Sargent's work both textually and visually, a cultural seer looking back from the end. The piece would also repeatedly frame her own texts, appearing as a frontispiece to her volumes of poetry both during her lifetime and after her death. ${ }^{65}$

Despite the eventual very public (reproduced) contexts for Whistler's portrait of Pennell and Sargent's portrait of Meynell, both retain visual traces of their private function through their dedicatory inscriptions. In both cases we can see that rather than passive sitters these women critics were as involved in constructing the artist as public self, as the artist was involved in constructing them within late nineteenth-century codes of femininity. Concomitantly, while articulating a carefully scripted version of Whistler and Sargent for the reading public, Pennell and Meynell consolidated their own visual authority at the finde-siècle.

\section{Acknowledgments}

Special thanks to the Leverhulme Foundation for funding this research. Many thanks to scholars in Canada, the United States, and the United Kingdom for their responses to earlier versions of this work, especially Patricia Berman, Sue Canning, and Susan Sidlauskas (College Art Association, Seattle). I am extremely grateful to the guest-editors of this volume, Lara Perry and Eva Major-Marothy, the RACAR editorial board and anonymous readers, as well as colleagues at the University of Sussex.

\section{Notes}

1 Kenneth McConkey, Memory and Desire: painting in Britain and Ireland at the turn of the twentieth century (Aldershor, U.K., 2002), 94.

2 Margaret F. MacDonald et al., Whistler, Women and Fashion (New Haven, 2003).

3 For an examination of their career histories, see M. Clarke, Critical Voices: Women and Art Criticism in Britain 1880-1905 (Aldershot, U.K., 2005).

4 Catalogue of a Collection of Lithographs by James McNeil Whistler with a prefatory note by Joseph Pennell, exh. cat., Fine Art Society (London, December 1895). The Firelight lithographs were not included in the first December 1895 edition of the catalogue; thcy were completed after it was printed and added to the show in January of 1896. See the catalogue raisonné of Whistler's lithographs, N. Smale et al., The Lithographs of James McNeill Whistler (Chicago, 1998), 295-98, 416-23.

5 E.R. Pennell and J. Pennell, The life of James McNeill Whistler, II (London, 1909), 169.

6 Special thanks to Margaret MacDonald for her helpful discussions concerning this portrait. Margaret MacDonald, "Palaces in the
Night: Selection and Symbolism in Whistler's Prints," The Whistler Review: Studies on James McNeill Whistler and Nineteenth-Century Art, eds Margaret Tedeschi and Nigel Thorp (Glasgow, 2003), 14 15.

7 Katharine Lochnan in The Lithographs of James McNeill Whistler, 106-7; Katharine Lochnan, TurnerWhistlerMonet: Impressionist Visions, exh. cat., Toronto, Art Gallery of Ontario (Toronto, 2004), $169,184$.

8 Alice Meynell, Collected Poems of Alice Meynell (London, 1913).

9 Elizabeth Prettejohn, Interpreting Sargent (London, 1998), 56.

10 Lara Perry, History's Beauties: Women in the National Portrait Gallery, 1856-1899, (Aldershot, U.K., 2006).

11 Acquisition File 2221, National Portrait Gallery.

12 See Perry, History's Beauties.

13 See Aileen Ribeiro, "Fashion and Whistler," Whistler, Women and Fashion (New Haven, 2003), 16-52.

14 "[Meynell] took particular pains in the use of draped garments and high heels to make herself appear as tall as possible." Vita Sackville West, in the introduction to Prose and Poetry. Centenary volume, eds Fredcrick Page, Viola Meynell, Olivia Sowerby, and Francis Meynell (London, 1947), 8.

15 Both of these women were writing for papers associated with the sensational New Journalism. The Star and the Pall Mall Gazette claimed to be producing news for the masses. See Laurel Brake, Print in Transition, 1850-1910: Studies in Media and Book History (Palgravc, 2001).

16 Angela Rosenthal, "She's got the look! Eighteenth-century female portrait painters and the psychology of a potentially 'dangerous employment'," Portraiture: Facing the Subject, ed. Joanna Woodall (Manchester and New York, 1997), 147-66.

17 Paul Barlow, "Facing the past and present: the National Portrait Gallery and the Search for 'Authentic' Portraiture," Portraiture: Facing the Subject, 219-38.

18 Linda Merrill, A Pot of Paint: Aesthetics on trial in Whistler $v$ Ruskin (Washington and London, 1992).

19 See Annc Koval, "The 'Artists' have come out and the 'British' remain: the Whistler faction at the Society of British Artists," After the Pre-Raphaelites: Art and Aestheticism in Victorian England, ed. Elizabeth Prettejohn (Manchester, 1999), 90-114.

20 The Freer Gallery recently recreated Whistler's controversial installations: "Arrangement in White and Yellow," Fine Art Society (1883), and "Arrangement in Flesh Colour and Grey," Dowdeswells' Gallery (1884). See Kenneth Myers, Mr. Whistler's gallery: pictures at an 1884 exhibition (London, 2003); David Park Curry, James McNeill Whistler: uneasy pieces (Richmond, New York, 2004). See also J. McNeill Whistler, Mr. Whistler's "Ten o'clock." [A lecture on Art] (London, 1888).

21 See also D.S.M., Spectator 2 April 1892, in M. Borland, D.S. MacColl: Poet, Painter, Art Critic (London, 1995), 72; Richard Dorment, "James McNeill Whistler," James McNeill Whistler, eds Richard Dorment and Margaret F. Macdonald (Iondon, 1995), 13-22.

22 N.N., "Mr. Whistler's Triumph," Nation, 14 April 1892, 280-81.

23 N.N., "Mr. Whistler's Triumph." 
24 N.N., "Mr. Whistler's Triumph."

25 Richard Ormond, "Sargent's Art," John Singer Sargent, eds Elaine Kilmurray and Richard Ormond (London, 1998), 32-33; Prettejohn, Interpreting Sargent, 66-70.

26 See Nicolai Cikovsky Jr with Charles Brock, "Whistler and America," James McNeill Whistler, eds Dorment and Macdonald, 37-38.

27 The Alhambra lithographs were also reproduced in an article for the Century magazine (1896), which Elizabeth Pennell wrote and her husband illustraced.

28 See Harriet Stratis, "Whistlcr's Prints and Their Transfer Papers: A Technical Study," The Whistler Review: Studies on James McNeill Whistler and Nineteenth-Century Art, 18-26.

29 See "Art Criticism.-Question of Lithographs.-Damages for Libel," Daily Chronicle, 7 April 1897; "Mr. Whistler as a Witness," Critic, 22 May 1897, 361.

30 Sarah Burns, Inventing the Modern Artist: Art and Culture in Gilded Age America (New Haven and London, 1996), 241.

31 Julie Codell, The Victorian Artist: artists' lifewritings in Britain, ca. 1870-1910 (Cambridge, 2003).

32 N.N., "Sir John Everett Millais," Nation, 27 August 1896, 15657.

33 A.U., "The Royal Academy," Star, 2 May 1893, 2.

34 A.U., "Grafton Gallery," Star, 23 Fcbruary 1893, 4.

35 James McNeill Whistler to Helen Euphrosyne Whistlcr, 23 July 1895, GUW 06732, MS Whistler W726, Glasgow University Archives.

36 A.M., "The Royal Academy," Weekly Register, 1 May 1886, 557.

37 Elaine Ormond and Richard Kilmurray, John Singer Sargent: Portraits of the 1890s (New Haven, Conn. and London, 2002), 5.

38 [A.M.], "Men and Things," Weekly Register, 30 April 1887, 564.

39 Alice Meynell, "Pictures from the Hill Collection," Magazine of Art, 1882, 80-84.

40 A.M., "Royal Academy," Weekly Register, 21 May 1887, 661.

41 A.M., "Royal Academy," Weekly Register, 21 May 1887, 661.

42 Anne L. Helmreich, "John Singer Sargent, Carnation, Lily, Lily, Rose, and the Condition of Modernism in England, 1887," Victorian Studies 45, 3 (August 2003), 448.

43 A.M., "Royal Acadcmy," Weekly Register, 21 May 1887, 661-62.

44 [A.M.], "The Royal Academy," Weekly Register, 12 May 1888, 598; Alice Meynell, "Newlyn," Art Journal, 1889, 97-102, 137-42.

45 Viola Meynell, Alice Meynell: A Memoir (London, 1929), 215.

46 Alice Meynell to John Lane, 3 August, n.d. [1890s], M.14, Burns Library, Boston College University.

47 For example: Coventry Patmore, "Mrs. Meynell Poet and Essayist," Fortnightly Review, July-December 1892, 76; George Meredith, "Mrs. Meynell's Essays," New Review, March-August 1896, 762.

48 Max Beerbohm, "Mrs. Meynell's Cowslip Wine," Tomorrow, September 1896, a review of Meynell, The Colour of Life (London and New York, 1896).

49 Alice Meynell to Wilfrid Meynell, 19 1)ecember 1902, private collection. In a letter to Meynell after the book had come out
Sargent sought her advice and collaboration on a Madonna piece he was working on. John Singer Sargent to Alice Meynell, 5 February 1904, Special Collections, Syracusc University.

50 "The Royal Academy," Pall Mall Gazette, 2 May 1903, 1; "May Exhibitions," Pall Mall Gazette, 20 May 1903, 11.

51 Trevor Fairbrother, John Singer Sargent: the sensualist (New Haven and London, 2(000), 34.

52 J. Badeni, The Slender Tree: a life of Alice Meynell (Padstow, U.K., 1981), 172.

53 El Jaleo, 1880, Isabella Stewart Gardner Muscum, Boston; Javanese Dancer, 1889, private collection; President Theodore Roosevelt, 1903, The White House, Washington, D.C.; Madame Pierre Gautreau (Madame X), 1884, Metropolitan Museum of Art, New York; Ena and Betty, Daughters of Asher and Mrs. Wertheimer, 1901, Tate Britain, I.ondon.

54 Ormond and Kilmurray, John Singer Sargent: Portraits of the 1890s, 6; K. Adler, "John Singer Sargent's Portraits of the Wertheimer Family," The Jew in the Text: Modernity and the Construction of Identity, eds Linda Nochlin and Tamar Garb (London, 1995), 8396. Mary Cowling traces the relationship between physiognomy, anthropology, and Vicrorian art in The Artist as Anthropologist: the Representation of Type and Character in Victorian Art (Cambridge, U.K., 1989).

55 See E. Said, Orientalism (London, 1978); R. Lewis, Gendering Orientalism: Race, Femininity and Representation (London, 1996); J. Codell and D. S. Macleod, eds, Orientalism Transposed: The Impact of the Colonies on British Culture (Aldershot, U.K., 1998).

56 A.M. to W.M., 8 December 1902, private collection; Ormond and Kilmurray, John Singer Sargent: Portraits of the 1890s, 6. See L. Bland, Banishing the Beast: English Feminism and Sexual Morality, 1885-1914 (London, 1995).

57 Alice Meynell, The Work of John S. Sargent R.A. (London, 1903).

58 Elizabeth Robins Pennell and Joseph Pennell, The Life of James McNeill Whistler (London, 1908), 2 vols.

59 T.F.U. to J.P., 8 October 1898, Box 268, Penncll Collection, Library of Congress.

60 T.F.U. to J.P., 7 December 1898, Box 268, Pennell Collection, Library of Congress.

61 Ludmilla Jordanova, Defining Features: Scientific and Medical Portraits 1660-2000 (London, 2000), 16-20.

62 See Lochnan in The Lithographs of James McNeill Whistler, 423.

63 Jacques Derrida, Acts of Literature, ed. Derek Attridge (I.ondon, 1991), 69. See also Derrida, Signésponge/Signsponge, trans. Richard Rand (New York, 1984).

64 Jacques Derrida and Gcoffrey Bennington, Jacques Derrida (London and Chicago, 1993), 148-66.

65 Alice Mcynell, The Poems of Alice Meynell. Complete Edition [With portraitl (London, 1923). The portrait reappcared in an exhibition catalogue and volumes on the centcnary of her birth in 1947: Francis Meynell, Catalogue of the centenary exhibition of books, manuscripts, letters and portraits, etc., (London, 1947); Prose and Poetry. Centenary volume (London, 1947). 